\title{
Effect of Foliar Spray of Micronutrients and Growth Regulators on Seed Quality of Onion
}

\author{
Ashok $^{1}$ *, Basave Gowda ${ }^{1}$, S.R. Doddagoudar ${ }^{1}$, S.N. Vasudevan ${ }^{4}$, \\ M.G. Patil ${ }^{2}$ and Arunkumar Hosamani ${ }^{3}$
}

${ }^{1}$ Department of Seed Science and Technology, ${ }^{2}$ Department of Horticulture, ${ }^{3}$ Department of Agricultural Entomology, UAS, Raichur-584 104, ${ }^{4} A D R$, Department of Seed Science and Technology, University of Agricultural Sciences, Bangalore, India

*Corresponding author

\begin{abstract}
A B S T R A C T
Keywords

Onion, Seed

Production, Seed

quality, Growth

regulators and

Micronutrients

Article Info

Accepted:

04 March 2019

Available Online:

10 April 2019

The field experiment was carried out to study the effect of foliar spray of micronutrients and growth regulators on seed quality of onion during rabi 2016-17 and 2017-18 at Seed Unit, UAS, Raichur. Foliar spray was given at 45 and 75 days after bulb planting (DAP). The seed quality parameters were recorded at Seed Unit, UAS, Raichur. From the present investigation, a significant increase in seed quality parameters were recorded with foliar spray of $\mathrm{ZnSO}_{4} @ 0.5$ per cent viz., root length $(12.92,12.74$ and $12.83 \mathrm{~cm})$, shoot length (9.51, 9.59 and $9.55 \mathrm{~cm}$ ), seedling vigour index (2026, 2049 and 2037), seedling dry weight (36.0, 36.8 and $36.4 \mathrm{mg})$, dehydrogenase enzyme activity (2.612, 2.617 and 2.615 OD value) and $\alpha$-amylase enzyme activity $(18.70,19.67$ and $19.18 \mathrm{~mm})$ followed by GA3 @ 100 ppm over control viz., $(11.38,11.30$ and $11.34 \mathrm{~cm}, 8.33,8.87$ and $8.60 \mathrm{~cm}, 1773$, 1823 and $1798,32.5,35.3$ and $33.9 \mathrm{mg}, 2.586,2.593$ and $2.590 \mathrm{OD}$ value and $18.16,18.47$ and $18.32 \mathrm{~mm}$ ) during 2016-17, 2017-18 and pooled data, respectively. The non significant differences were observed due to influence of foliar spray of micronutrient and growth regulators on seed germination per cent and electrical conductivity.
\end{abstract}

\section{Introduction}

Onion (Allium cepa L.) is one of the important commercial vegetable crops grown in India. It is widely grown in different parts of the country mainly by small and marginal farmers. Onion is cross pollinated crop and efficient pollination depends largely on presence of insects in the area and their activity at flowering time. It is essential to ensure that there is sufficient population of pollinating insects including honeybees to achieve the full potential of onion seed and consequent higher seed yield. India produces around 168 lakh tons of onion annually ranking second in the world. The production has increased more than five times during past three decades. The reason for increase in 
production is mainly due to increase in area under onion cultivation from 1.94 lakh ha during 1974-75 to 10.51 lakh ha in 2016-17. Onion is extremely important vegetable crop not only for internal consumption but also as highest foreign exchange earner among the fruits and vegetables. It occupies an area of 1064 thousand ha, with production of 15118 thousand tons. India is the 2nd largest producer of onion, in the world next only to China but the productivity of onion in India is very low i.e. 14.21 tons/ ha as compared to China and other countries like, Egypt, Netherlands and Iran etc., (Annon., 2017).

The major onion producing states are Maharashtra, Madhya Pradesh, Karnataka, Gujarat, Rajasthan, Bihar, Andhra Pradesh, Haryana, West Bengal, Uttar Pradesh, Chhattisgarh, Odisha, Tamil Nadu, Jharkhand and Telangana in the country. These states account for 97 per cent of the total production of the country. As per the third advance estimates, the production of onion during the year $2016-17$ is likely to be 3.8 per cent higher from the previous year. Among the different onion growing states, Maharashtra is the major onion producing state with 30.41 per cent of production share, followed by Karnataka, Madhya Pradesh, Rajasthan and Gujarat with 15.51, 13.66, 6.49 and 6.31 per cent share, respectively during year 2016-17.

Intensive cropping, imbalanced fertilization and minimal usage of micronutrients and limited application of organic manures have resulted in the depletion of soil fertility in India. Boron and zinc are the most important micro-nutrients and are essential for cell division, nitrogen and carbohydrate metabolism and water relation in plant growth (Brady, 1990). Application of boron can increase bulb size, number of cloves/bulb and yield of onion (Smriti et al., 2002). Mishra et al., (1990) have shown that application of $\mathrm{ZnSO}_{4}(0.5 \%)$ and $\mathrm{FeSO}_{4}(1.0 \%)$ as foliar spray recorded significantly higher plant height and other growth parameters as compared to other treatments in onion.

Plant growth regulators are new generation agro chemicals and are expected to play an important role in overcoming the hurdles in manifestation of biological yield. In recent years, plant growth regulators are used to overcome the factors that limiting the growth and yield to obtain maximum benefit from seed production. It is revealed from experiments conducted in various part of the world that IAA, NAA, GA 3 , IBA, TIBA and Ethrel at various concentrations have remarkable effects on number of flowers per umbel, umbel size and quality seed production of onion. The objective of this study is to determine the influence of foliar sprays of micronutrients and growth regulators on seed quality of onion.

\section{Materials and Methods}

The present investigation was carried out to determine the influence of foliar spray of micronutrients and growth regulators on the seed quality of onion at Seed production plot, Seed Unit, Plot No. 187, University of Agricultural Sciences, Raichur during rabi 2016-17 and 2017-18. The experiment includes total 8 treatments involving foliar spray of micronutrients $\left(\mathrm{T}_{2}: \mathrm{ZnSO}_{4} @ 0.5 \%\right.$, $\mathrm{T}_{3}$ : B@0.5\% and $\mathrm{T}_{4}: \mathrm{T}_{2}+\mathrm{T}_{3}$ ) and growth regulators $\left(\mathrm{T}_{5}\right.$ : GA 3 @100 ppm, T6: NAA @ 100 ppm, $\mathrm{T}_{7}: \mathrm{T}_{5}+\mathrm{T}_{6}$ and $\mathrm{T}_{8}$ : TIBA @ 240 ppm + NAA @ 50 ppm) and with the reference $\mathrm{T}_{1}$ (Control) replicated thrice. Foliar spray was given at 45 and 75 DAP. The row spacing of $45 \mathrm{~cm}$ and between plants $30 \mathrm{~cm}$ was maintained in plot size of $4.05 \mathrm{~m}$ length and $2.10 \mathrm{~m}$ breadth. The effect of foliar spray of micronutrients and growth regulators on seed quality of onion were assessed in terms of their effect on seed following below mentioned quality parameters viz., 


\section{Seed germination $(\%)$}

The laboratory germination test was conducted in four replications of 100 seeds each as per the ISTA rules (Anon., 2014) by adopting "between paper method". The seeds were uniformly placed on germination paper and were kept in germinator maintained at alternate temperature of $25 \pm 2{ }^{\circ} \mathrm{C}$ and $95 \pm 5$ per cent relative humidity. The number of normal seedlings was counted at the end of twelve days of the test and germination was expressed in percentage (\%).

\section{Shoot length (cm)}

Randomly selected ten normal seedlings from germination test were used and the shoot length was measured from collar region to the point of attachment of cotyledon and mean was worked out and expressed in centimetre (cm).

\section{Root length $(\mathrm{cm})$}

Seedlings used for shoot length measurement were also used for measuring root length. The length of root was measured from collar region to the tip of primary root and was expressed as mean root length in centimetre (cm).

\section{Seedling vigour index (SVI)}

The seedling vigour index was worked out by multiplying the per cent germination and total seedling length (Abdul-Baki and Anderson, 1973).

Seedling Vigour Index $=$ Germination $\% \times$ Total seedling length $(\mathrm{cm})$

\section{Seedling dry weight (mg) per ten seedlings}

Earlier ten normal seedlings chosen for measuring shoot and root length were used to determine seedling dry weight. The seedlings were kept in butter paper bag and were dried in hot air oven at $70 \pm 2{ }^{\circ} \mathrm{C}$ for 24 hours. After drying, they were cooled in desiccators for 30 minutes and were weighed on an electronic balance. Their average weight of 10 seedlings was expressed in milligram $(\mathrm{mg})$ per ten seedlings (Evans and Bhatt, 1977).

\section{Electrical conductivity of seed leachate $\left(\mathrm{dSm}^{-1}\right)$}

Electrical conductivity of seed leachate was determined as per method given by Presley (1958). Five grams of seeds were surface sterilized by using 0.1 per cent mercuric chloride solution and washed twice with distilled water. Then $25 \mathrm{ml}$ distilled water was added to the seeds and kept in the incubator maintained at $25{ }^{\circ} \mathrm{C}$ temperature for 24 hours and the seed leachate was collected. The seed leachate was collected and volume was made up to $25 \mathrm{ml}$ by adding distilled water. The electrical conductivity of the seed leachate was measured in the digital conductivity bridge with a cell constant of 1.0 and the mean values were expressed in deci simons per metre $\left(\mathrm{d} \mathrm{Sm}^{-1}\right)$.

\section{$\alpha$-amylase enzyme activity (mm)}

The $\alpha$-amylase activity was analyzed as per the method suggested by Simpson and Naylor (1962). Two gram of agar shreds and one gram of potato starch was mixed together in water to form paste and the volume was made up to $100 \mathrm{ml}$ with distilled water. The homogenous solution of agar-starch mixture after boiling was poured into sterilized petridishes and allowed to settle in the form of gel after cooling. The pre-soaked (for 8 hour) and half cut seeds (with their half endosperm and embryo portion intact) were placed in the petri-dishes in such a way that the endospermic part remained in contact with agar-starch gel. The petri-dishes were closed 
and kept in dark at $30{ }^{\circ} \mathrm{C}$. After 48 hour the petri-dishes were uniformly smeared with potassium iodide solution $(0.44 \mathrm{~g}$ of iodine crystal $+20.008 \mathrm{~g}$ potassium iodide in $500 \mathrm{ml}$ distilled water) and excess solution was drained off after few minutes. The diameter of halo (clear) zone formed around the seed was measured in $\mathrm{mm}$ and reported as $\alpha$ - amylase activity.

\section{Dehydrogenase enzyme activity (OD value)}

Twenty five representative seeds from each treatment in two replications were taken and preconditioned by soaking in water overnight at room temperature. Embryos were exercised from the seeds and were steeped in 0.25 per cent solution of 2, 3, 5-triphenyl tetrazolium chloride and kept in dark for two hours at 40 ${ }^{0} \mathrm{C}$ for staining. The stained seeds were thoroughly washed with water and then soaked in ten $\mathrm{ml}$ of 2 methoxy ethanol (methyl cellosolve) and kept overnight for extracting the red colour formazan. The intensity of red colour was measured using ELICO UV-VIS spectrophotometer (model SC-159) using blue filter at $470 \mathrm{~nm}$ wave length and methyl cellosolve was used as a blank. The OD value obtained was reported as dehydrogenase activity (Kittock and Law, 1968).

\section{Results and Discussion}

\section{Seed quality parameters}

The foliar sprays of micronutrients and growth regulators have resulted in improved quality parameters in onion. Among foliar sprays, $\mathrm{ZnSO}_{4} @ 0.5$ per cent $\left(\mathrm{T}_{2}\right)$ exhibited higher values for all the seed quality parameters followed by $\mathrm{GA}_{3} @ 100$ ppm $\left(\mathrm{T}_{5}\right)$, Boron@0.5\% ( $\left.\mathrm{T}_{3}\right)$, NAA @ 100 ppm $\left(\mathrm{T}_{6}\right)$, $\mathrm{T}_{4}\left(\mathrm{~T}_{2}+\mathrm{T}_{3}\right)$, NAA @ 50 ppm and TIBA @ $240 \mathrm{ppm}\left(\mathrm{T}_{8}\right), \mathrm{T}_{7}\left(\mathrm{~T}_{5}+\mathrm{T}_{6}\right)$ and the lowest in control $\left(\mathrm{T}_{1}\right)$.
Seed germination do not differed significantly due to influence of foliar spray (Table 1). Significantly maximum root length was recorded with foliar spray of $\mathrm{ZnSO}_{4} @ 0.5$ per cent $\left(\mathrm{T}_{2}\right)(12.92,12.74$ and $12.83 \mathrm{~cm}$ during 2016-17, 2017-18 and pooled data of two years, respectively). While, the minimum root length was recorded in control $\left(\mathrm{T}_{1}\right)(11.38$, 11.30 and $11.34 \mathrm{~cm}$ during 2016-17, 2017-18 and pooled data of two years, respectively) (Table 1). Significantly maximum shoot length was recorded with foliar spray of $\mathrm{ZnSO}_{4} @ 0.5$ per cent $\left(\mathrm{T}_{2}\right)(9.51,9.59$ and $9.55 \mathrm{~cm}$ during 2016-17, 2017-18 and pooled data of two years, respectively). While, the minimum shoot length was recorded in control $\left(\mathrm{T}_{1}\right)(8.33,8.87$ and $8.60 \mathrm{~cm}$, during 2016-17, 2017-18 and pooled data of two years, respectively) (Table 1). The higher seedling vigour index (2026, 2049 and 2037 during 2016-17, 2017-18 and pooled mean data of two years, respectively) was recorded with foliar spray of $\mathrm{ZnSO}_{4} @ 0.5$ per cent $\left(\mathrm{T}_{2}\right)$ over control $\left(\mathrm{T}_{1}\right)(1773,1823$ and 1798 during 2016-17, 2017-18 and pooled mean data of two years, respectively) (Table 2). The treatment foliar spray of $\mathrm{ZnSO}_{4} @ 0.5$ per cent $\left(\mathrm{T}_{2}\right)$ recorded higher seedling dry weight (36.0, 36.8 and $36.4 \mathrm{mg}$ during 2016-17, 2017-18 and pooled mean data of two years, respectively) over control $\left(\mathrm{T}_{1}\right)(32.5,35.3$ and $33.9 \mathrm{mg}$ during 2016-17, 2017-18 and pooled mean data of two years, respectively). The electrical conductivity was found to be differed non significantly due to the influence of foliar spray (Table 2).

The foliar spray of $\mathrm{ZnSO}_{4} @ 0.5$ per cent $\left(\mathrm{T}_{2}\right)$ recorded higher dehydrogenase activity (2.612, 2.611 and 2.609 during 2016-17, 2017-18 and pooled mean data of two years, respectively) over control $\left(\mathrm{T}_{1}\right)(2.586,2.593$ and 2.590 during 2016-17, 2017-18 and pooled mean data of two years, respectively) (Table 3). 
Table.1 Effect of foliar spray of micronutrients and growth regulators on seed germination, root length and shoot length in onion seed production

\begin{tabular}{|c|c|c|c|c|c|c|c|c|c|}
\hline \multirow[t]{2}{*}{ Treatments } & \multicolumn{3}{|c|}{ Seed germination $(\%)$} & \multicolumn{3}{|c|}{ Root length (cm) } & \multicolumn{3}{|c|}{ Shoot length (cm) } \\
\hline & 2016-17 & 2017-18 & Pooled & 2016-17 & 2017-18 & Pooled & 2016-17 & 2017-18 & Pooled \\
\hline $\mathbf{T}_{1-}$ - Control & $\begin{array}{c}88.67 \\
(70.35)\end{array}$ & $\begin{array}{c}90.00 \\
(71.57)\end{array}$ & $\begin{array}{c}89.33 \\
(70.96)^{*}\end{array}$ & 11.38 & 11.30 & 11.34 & 8.33 & 8.87 & 8.60 \\
\hline $\mathrm{T}_{2}-\mathrm{ZnSO}_{4} @ 0.5 \%$ & $\begin{array}{c}91.33 \\
(72.88)\end{array}$ & $\begin{array}{c}91.67 \\
(73.23)\end{array}$ & $\begin{array}{c}91.50 \\
(73.06)\end{array}$ & 12.92 & 12.74 & 12.83 & 9.51 & 9.59 & 9.55 \\
\hline $\mathbf{T}_{3}-\mathbf{B} @ 0.5 \%$ & $\begin{array}{c}90.00 \\
(71.58)\end{array}$ & $\begin{array}{c}91.00 \\
(72.56)\end{array}$ & $\begin{array}{c}90.50 \\
(72.07)\end{array}$ & 11.78 & 11.76 & 11.77 & 9.05 & 9.38 & 9.22 \\
\hline $\mathbf{T}_{4}-\mathbf{T}_{2}+\mathbf{T}_{3}$ & $\begin{array}{c}89.33 \\
(70.95)\end{array}$ & $\begin{array}{c}90.67 \\
(72.22)\end{array}$ & $\begin{array}{c}90.00 \\
(71.59)\end{array}$ & 11.36 & 11.35 & 11.36 & 8.79 & 9.05 & 8.92 \\
\hline $\mathbf{T}_{5^{-}} \mathbf{G A}_{3} @ 100$ ppm & $\begin{array}{c}91.00 \\
(72.56)\end{array}$ & $\begin{array}{c}91.33 \\
(72.88)\end{array}$ & $\begin{array}{c}91.17 \\
(72.72)\end{array}$ & 12.02 & 12.65 & 12.34 & 9.37 & 9.46 & 9.41 \\
\hline T6- NAA@ 100 ppm & $\begin{array}{c}89.33 \\
(70.97)\end{array}$ & $\begin{array}{c}90.67 \\
(72.22)\end{array}$ & $\begin{array}{c}90.00 \\
(71.59)\end{array}$ & 11.54 & 11.66 & 11.60 & 8.83 & 9.35 & 9.09 \\
\hline $\mathbf{T}_{7}-\mathbf{T}_{5}+\mathbf{T}_{6}$ & $\begin{array}{c}88.33 \\
(70.05)\end{array}$ & $\begin{array}{c}90.00 \\
(71.58)\end{array}$ & $\begin{array}{c}89.17 \\
(70.82)\end{array}$ & 11.36 & 11.33 & 11.35 & 8.69 & 8.96 & 8.83 \\
\hline T8- TIBA@ 240 ppm + NAA @ 50 ppm & $\begin{array}{c}90.00 \\
(71.58)\end{array}$ & $\begin{array}{c}90.33 \\
(71.89)\end{array}$ & $\begin{array}{c}90.17 \\
(71.74)\end{array}$ & 11.38 & 11.50 & 11.44 & 8.81 & 9.17 & 8.99 \\
\hline Mean & $\begin{array}{c}89.71 \\
(71.37)\end{array}$ & $\begin{array}{c}90.71 \\
(72.27)\end{array}$ & $\begin{array}{c}90.23 \\
(71.82)\end{array}$ & 11.72 & 11.79 & 11.75 & 8.92 & 9.23 & 9.08 \\
\hline S.Em \pm & 0.34 & 0.44 & 0.30 & 0.24 & 0.26 & 0.21 & 0.10 & 0.07 & 0.07 \\
\hline $\mathrm{CD}$ at $5 \%$ & NS & NS & NS & 0.73 & 0.80 & 0.63 & 0.31 & 0.22 & 0.21 \\
\hline
\end{tabular}

* Figures in the parentheses indicates arc sine transformed values

Note: Foliar spray was given at 45 and 75 DAP 
Table.2 Effect of foliar spray of micronutrients and growth regulators on seedling vigour index, seedling dry weight and electrical conductivity in onion seed production

\begin{tabular}{|c|c|c|c|c|c|c|c|c|c|}
\hline \multirow[t]{2}{*}{ Treatments } & \multicolumn{3}{|c|}{ Seedling vigour index } & \multicolumn{3}{|c|}{ Seedling dry weight (mg) } & \multicolumn{3}{|c|}{ Electrical conductivity $\left(\mathrm{dSm}^{-1}\right)$} \\
\hline & 2016-17 & 2017-18 & Pooled & 2016-17 & 2017-18 & Pooled & 2016-17 & 2017-18 & Pooled \\
\hline $\mathbf{T}_{1^{-}}$Control & 1773 & 1823 & 1798 & 32.5 & 35.3 & 33.9 & 0.442 & 0.429 & 0.436 \\
\hline $\mathrm{T}_{2}-\mathrm{ZnSO}_{4} @ 0.5 \%$ & 2026 & 2049 & 2037 & 36.0 & 36.8 & 36.4 & 0.431 & 0.421 & 0.426 \\
\hline$T_{3}-B @ 0.5 \%$ & 1881 & 1911 & 1896 & 35.5 & 36.2 & 35.8 & 0.431 & 0.424 & 0.427 \\
\hline$T_{4}-T_{2}+T_{3}$ & 1826 & 1837 & 1832 & 35.1 & 35.9 & 35.5 & 0.435 & 0.423 & 0.429 \\
\hline $\mathbf{T}_{5^{-}} \mathbf{G A}_{3} @ 100$ ppm & 1996 & 1933 & 1965 & 35.7 & 36.5 & 36.1 & 0.432 & 0.425 & 0.429 \\
\hline 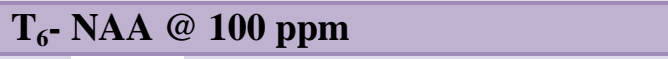 & 1851 & 1887 & 1869 & 35.3 & 36.0 & 35.7 & 0.433 & 0.424 & 0.429 \\
\hline $\mathbf{T}_{7}-\mathbf{T}_{5}+\mathbf{T}_{6}$ & 1809 & 1829 & 1819 & 34.9 & 35.8 & 35.4 & 0.435 & 0.426 & 0.430 \\
\hline T8- TIBA@ 240 ppm + NAA @ 50 ppm & 1835 & 1850 & 1842 & 35.2 & 35.8 & 35.5 & 0.438 & 0.424 & 0.431 \\
\hline Mean & 1874 & 1890 & 1882 & 35.0 & 36.0 & 35.5 & 0.435 & 0.424 & 0.430 \\
\hline S.Em \pm & 26 & 28 & 21 & 0.2 & 0.2 & 0.2 & 0.006 & 0.004 & 0.004 \\
\hline CD at $5 \%$ & 80 & 84 & 64 & 0.6 & 0.7 & 0.5 & NS & NS & NS \\
\hline
\end{tabular}

DAT: Days after bulb planting

NS: Non Significant

Note: Foliar spray was given at 45 and 75 DAP 
Table.3 Effect of foliar spray of micronutrients and growth regulators on dehydrogenase activity and $\alpha$-amylase enzyme activity in onion seed production

\begin{tabular}{|c|c|c|c|c|c|c|}
\hline \multirow[t]{2}{*}{ Treatments } & \multicolumn{3}{|c|}{ Dehydrogenase activity (OD value) } & \multicolumn{3}{|c|}{$\alpha$-amylase enzyme activity (mm) } \\
\hline & 2016-17 & 2017-18 & Pooled & 2016-17 & 2017-18 & Pooled \\
\hline T1- Control & 2.586 & 2.593 & 2.590 & 18.16 & 18.47 & 18.32 \\
\hline T2-ZnSO4@0.5\%, & 2.612 & 2.617 & 2.615 & 18.70 & 19.67 & 19.18 \\
\hline T3-B@0.5\% & 2.607 & 2.611 & 2.609 & 18.57 & 19.47 & 19.02 \\
\hline $\mathrm{T} 4-\mathrm{T} 2+\mathrm{T} 3$ & 2.601 & 2.603 & 2.602 & 18.37 & 18.90 & 18.63 \\
\hline T5-GA3 @100 ppm & 2.609 & 2.615 & 2.612 & 18.63 & 19.50 & 19.07 \\
\hline T6-NAA@100 ppm & 2.602 & 2.610 & 2.606 & 18.50 & 19.30 & 18.90 \\
\hline $\mathrm{T} 7-\mathrm{T} 5+\mathrm{T} 6$ & 2.592 & 2.597 & 2.595 & 18.27 & 18.77 & 18.52 \\
\hline T8-TIBA@240 ppm+NAA@50 ppm & 2.603 & 2.604 & 2.603 & 18.51 & 19.07 & 18.79 \\
\hline Mean & 2.602 & 2.606 & 2.604 & 18.46 & 19.14 & 18.80 \\
\hline S.Em \pm & 0.004 & 0.004 & 0.003 & 0.10 & 0.22 & 0.12 \\
\hline CD at $5 \%$ & 0.013 & 0.012 & 0.011 & 0.32 & 0.68 & 0.38 \\
\hline
\end{tabular}

DAT: Days after bulb planting

Note: Foliar spray was given at 45 and 75 DAP 
Significantly maximum $\alpha$-amylase enzyme activity was recorded in $\mathrm{T}_{2}(18.70,19.67$ and $19.18 \mathrm{~mm}$ during 2016-17, 2017-18 and pooled data of two years, respectively) while, the minimum $\alpha$-amylase enzyme activity was recorded in control $\left(\mathrm{T}_{1}\right)(18.16,18.47$ and $18.32 \mathrm{~mm}$ during 2016-17, 2017-18 and pooled data of two years, respectively) (Table 3).

In general, we can infer that the spray of zinc influenced root and shoot length $(\mathrm{cm})$ and germination of onion. Moreover, the difference found when comparing control and zinc explained by early seed roots, enriched with zinc, are supplied as foliar source (Prado, 2007), improving germination and vigour (Ribeiro and Santos, 1996). Increase in seedlings initial performance after treatment with $\mathrm{ZnSO}_{4}$, was also verified by Prado (2007). Zinc, despite being an essential micronutrient, can affect growth and normal metabolism of plant species, present in excess levels in the environment, causing a phytotoxic effect (Albuquerque, 2010). According to Ribeiro and Santos (1996), the enhanced content in seeds of $\mathrm{ZnSO} 4$ about 18 times, was not toxic to corn seeds, allowing a greater supply of zinc to the beginning of seedling growth. It is believed that in the case of using seeds of low quality, the positive effect of zinc can be shown, as noted by Dalmolin (1992). However, small increases in germination and vigor, using the best quality seeds, can be reflected in more vigorous plants, large population and greater homogeneity of plants in field, and can, thereby, increase productivity and quality of seeds (Arjmand et al., 2014). The foliar spray of $\mathrm{ZnSO}_{4}$ improved the seed quality parameters which may be due to Zinc element involved in auxin metabolism plays a vital role in seed set, seed size and quality. Higher seed quality parameters noticed in the present study may be due to well developed seeds with higher test weight, lower electrical conductivity and higher dehydrogenase enzyme activity. Hence, additional supply of nutrients and direct availability of micronutrients to the plant which leads to the production of good quality seed. These results are in conformity with the findings of Rathinavel et al., (2000) in cotton. The application of $\mathrm{GA}_{3}$ increase the seed quality parameters might be due to more photosynthesis rate and better accumulation of food material in plant coupled with increasing growth character by cell division, cell elongation and cell enlargement that might have ultimately increased the seed weight and quality parameters. These findings are similar with Govind et al., (2015).

From the above results it is concluded that foliar spray of $\mathrm{ZnSO}_{4} @ 0.5$ per cent at 45 and 75 days after bulb planting (DAP) was best over other treatments for seed quality of onion.

\section{References}

Abdul-Baki, A. A. and Anderson, J. D. (1973). Vigour determination of soybean seeds by multiple criteria. Crop Sci., 13, 630-633.

Albuquerque, K. A. D., Oliveira, J. A., Veiga, A. D., Carvalho, B. O. and Alvim, P. O. (2010). Armazenamento e qualidade de sementes de tomate enriquecidas com micronutrientes e reguladores de crescimento. Ciência agrotecnologia, 34(1):20-28.

Anonymous (2017). Indian Horticulture Database. https://www.indiastat.com.

Arjmand, H. S., Gholam, H. B. A., Mansour, G. and Saeed, S. (2014). Effect of zinc coated during storage on the seed quality of barley. Int. J. Farming and Allied Sci., 3(8), 845-850.

Brady, N. C. (1990). The nature and properties and soils. $10^{\text {th }}$ edition, A. K. Ghosh. Printing-Hall of India Pvt. Ltd., 
New Delhi. p. 383.

Dalmolin, R. S. D. (1992). Fontes de zinco aplicadas nas sementes de milho cultivado em solução nutritiva com diferentes doses de zinco. 82p.. Dissertação (Mestrado em Agronomia) - Universidade Federal de Santa Maria, Santa Maria, RS.

Evans, L. E. and Bhatt, G. W. (1977). A non destructive technique for measuring seedling vigour in wheat. Canadian J. Pl. Sci., 57, 983-985.

Govind, S., Maji, R., Kumawat, A., Pal, S. K. and Saha, S. (2015). Improvement of growth, yield and quality of garlic (Allium sativum L.) Cv. G-282 through a novel approach. The Bioscan, 10(1), 23-27.

Kittock, P. A. and Law, A. G. (1968). Relationship of seedling vigour to respiration and tetrazolium chloride reduction of germinating wheat seeds. Agron. J., 60, 286-288.

Mishra, H. P., Singh, K. P. and Yadav, J. P. (1990). Influence of $\mathrm{Zn}, \mathrm{Fe}, \mathrm{B}$ and $\mathrm{Mn}$ and their uptake on onion grown in calcareous soil. Haryana J. Horti. Sci., 19(1\&2), 153-159.
Prado, R. M. (2007). Crescimento inicial e estado nutricional do trigo submetido à aplicação de zinco via semente. J. Soil Nutricion, 7(2), 22- 31.

Presley, J. T. (1958). Relation of protoplast permeability of cotton seed viability and pre deposition of disease. Plant Disease Report, 42, 582.

Rathinavel, K., Dharmalingam, C. and Selvan, S. P. (2000). Effect of seed pelleting on the productivity of rice fallow cotton (Gossypium hirsutum) cv. MCU-7. Advances of Pl. Sci., 13(1), 213-217.

Ribeiro, N. D. and Santos, O. S. (1996). Aproveitamento do zinco aplicado na semente na nutrição da planta. Ciência Rural, 26(1), 159-165.

Simpson, G. M. and Naylor, J. M. (1962). Dormancy studies in seed of Avern fatua. A relationship between maltase, amylases and gibberellin. Can. J. Bot., 40, 1659-1673.

Smriti. S., Kumar, R. and Singh, S. K. (2002). Effect of sulphur and boron nutrition on growth, yield and quality of onion (Allium cepa L.). J. Appl Bio., 12, 4046.

\section{How to cite this article:}

Ashok, Basave Gowda, S.R. Doddagoudar, S.N. Vasudevan, M.G. Patil and Arunkumar Hosamani. 2019. Effect of Foliar Spray of Micronutrients and Growth Regulators on Seed Quality of Onion. Int.J.Curr.Microbiol.App.Sci. 8(04): 337-345. doi: https://doi.org/10.20546/ijcmas.2019.804.037 